\title{
USING EXAMINATIONS OF YOUNG BLACK-HEADED GULLS (LARUS RIDIBUNDUS) FOR THE DETECTION OF SALMONELLAE IN THE ENVIRONMENT
}

\author{
I. LITERÁK, ${ }^{1}$ A. ČÍŽEK, ${ }^{2}$ M. HONZA ${ }^{3}$
}

Department of Epizootiology, University of Veterinary Science, 61242 Brno $^{\mathbf{l}}$

Department of Microbiology and Immunology, University of Veterinary Science, 61242 Brno $^{2}$ Institute of Systematic and Ecological Biology of the Czechoslovak Academy of Sciences, 60365 $\mathrm{Brno}^{3}$

Received September 27, 1991

\begin{abstract}
Literák I., A. Čížek, M. Honza: Using Examinations of Young Black-headed Gulls (Larus ridibundus) for the Detection of Salmonellae in the Environment. Acta vet. Brno, 61, 1992: 141 - 146.

During June 1991, cloacal smears from nestlings and chicks of black-headed gull (Larus ridibundus) of the nesting colonies in the middle reservoir of the water system Nové Mlýny (Břeclav district) were examined for the presence of salmonellae. On 13 June 1991, 96 yo ng gulls were examined and salmonellae were found in 20 gulls (i. e. $20.83 \%$ ), the serotypes being Salmonella typhimurium and $S$. derby. On 25 June 1991, 171 juvenile gulls were examined and salmonellae were found in 63 , i. e. $36.84 \%$ (S. typhimurium, S. enteritidis, S. agona, S. montevideo, S. derby, $S$. hadar, $S$. infantis and $S$. abony. On 16 May 1991, 79 eggs of black-headed gulls from the same colony were examined and no salmonellae were found.

It was proved that the water flowing into the reservoir from the river Jihlava and river Svratka in June 1991 was contaminated with salmonellae (i. e. S. typhimurium, S. montevideo).

Examinations of the juvenile black-headed gulls can be used for the detection of the occurrence of salmonellae in the water.
\end{abstract}

Salmonellae, black-headed gull (Larus ridibundus), eggs, nestlings, chicks, water

Analyses of the occurrence of epidemiological and epizootological alimentary infections and intoxication have shown that the situation has considerably changed over the recent 10 years. In the Czech Republic, the incidence of salmonelloses in the human and farm animal populations has increased rapidly, Salmonella enteritidis being the main source of epidemics (Dědičová et al. 1990; Šrámková et al. 1991). The main source of salmonellae is the intestinal tract of sick people and animals. The salmonellae there find favourable conditions for reproduction and through the faeces they get out into the environment. Due to their tenacity and rapid adaptability they find convenient living conditions, particularly in biological refuse. Consequently, they can be found in sewage water from municipal agglomerations, from slaughter-houses, from farm buildings, and also in surface waters (Reilly et al. 1981; Johnston et al. 1986; Komínková and Blatný 1987).

We tried to find out how the contamination of surface water would affect the incidence of salmonellae in populations of wild birds. The black-headed gulls (Larus ridibundus) were chosen as a model species because they are very numerous, partly synantrophic, and theyare in immediate contact with the water.

In Czechoslovakia, Š erý and Strauss (1957) drew attention to the incidence of salmonelloses in a colony of black-headed gulls. They isolated $S$. typhimurium in $77 \%$ of clinically ill and dead gulls. Literák and $\mathrm{Kraml}(1985)$ examined cloacal smears from 23 flying black-headed gulls of the Heřmanický pond near Ostrava. In one case they isolated S. typhimurium. Čížek (1990) dealt with the incidence of salmonellae in black-headed gulls, he examined 502 birds from various localities and he isolated 8 serotypes of salmonellae in $12.5 \%$. 


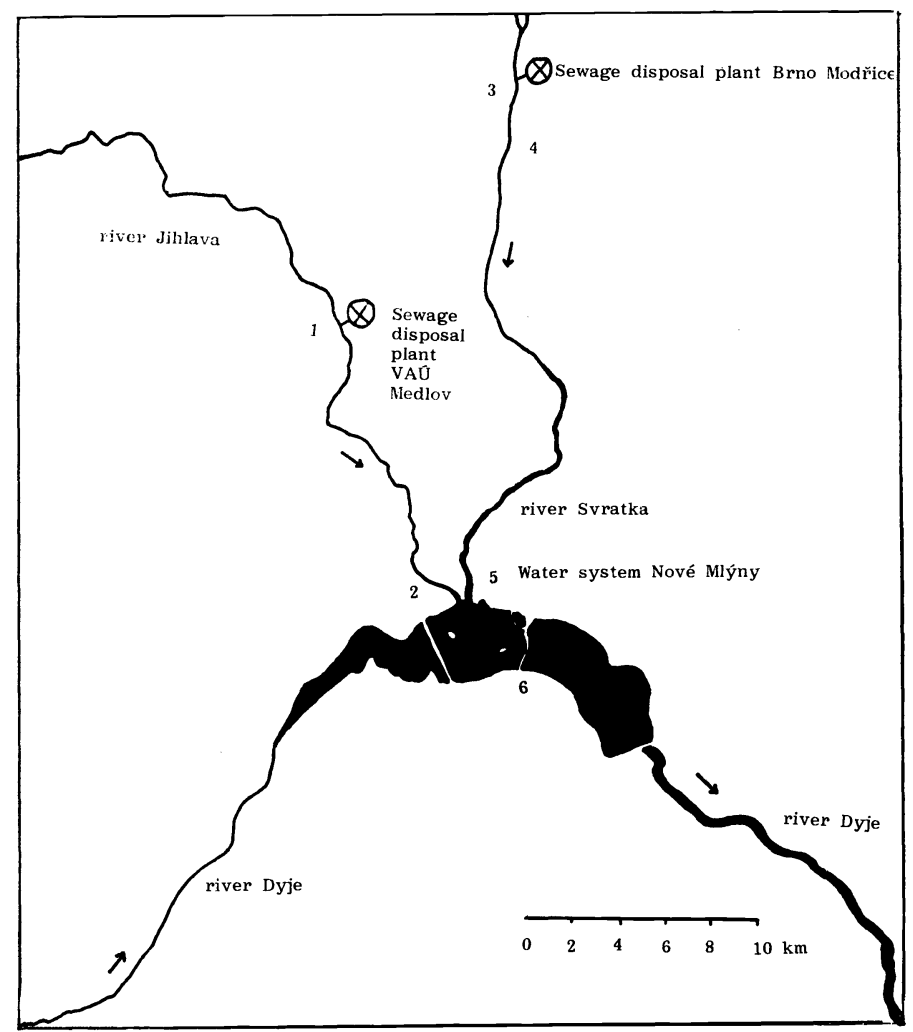

Fig. 1. Illustration of rivers in investigated regions $1-6$ where salmonellae were found in the water in June 1991.

Abroad, it was namely Coulson et al. (1983) and Fricker (1984) who studied the incidence of salmonellae in black-headed gulls. Couls on et al. (1983) examined 416 birds and in $2.9 \%$ their findings were positive. Fricker (1984) examined 1080 birds and in $17.7 \%$ he found 10 serotypes of salmonellae.

Further literary data refer to salmonellae in other species of gulls where the percentage of positive findings differed in dependence on the age of the gulls and type of feed (e. g. Williams et al. 1976; Edel et al. 1976; Fenlon 1981; Coulson et al. 1983; Butterfield et al. 1983; Monaghan et al. 1985; Glunder et al. 1991).

$\mathrm{Br}$ and et al. (1988) studied the causes of mortality of gulls. In groups of 99 and 96 specimens consisting of 4 species of gulls, he indicated salmonellosis as being the cause of mortality or disease in 10 and 5 cases, respectively.

\section{Materials and Methods}

The black-headed gulls were investigated and sampled for the occurrence of salmonellae in the middle water reservoir of the Nové Mlýny waterworks in the Břeclav district (Fig. 1). The reservoirs are built on the Dyje river below tha Pálava Hills. The rivers Jihlava and Svratka which, with the river Dyje, collect most of the water of South Moravia, flow into the middle reservoir. The area of the middle reservoir is $1031 \mathrm{ha}$, and the average depth is $3.4 \mathrm{~m}$.

In 1991, it was found that about 20,000 pairs of black-headed gulls nested on the islets of the middle reservoir. The birds nested in two similar colonies. One colony was on the islets in the place of what once was the village Mušov and the other on the islets near Dolni Věstonice. Adult 
birds which were not nesting were found in the reservoir along with the nesting birds and the young ones.

During the nesting period in 1991, the range of movements of the gulls was studied in 4 stable lines oriented to the four cardinal points. The length of one line was approximately $20 \mathrm{~km}$. Nearly all the adult gulls moved to their feeding sites within a radius of $15 \mathrm{~km}$ of the breeding colony. Longer distances were rare and, in essence, eliminated the possibility of nesting. It is a well-known fact that birds flying longer distances from the colony, use the colony only overnight during nesting.

From the breeding colony near Dolní Věstonice, samples were taken and examined of 79 eggs. on 16 May 1991, 96 cloacal smears from young birds not yet flying on 13 June 1991, and 171 cloacal smears from other not flying birds on 25 June 1991.

Using cotton swabs exposed for several days, waste water from the expected sources of contamination of the river was sampled in June 1991. Samples of water were taken of water discharged into the Svratka river after being cleaned in the sewage treatment plant in Brno-Modřice, and into the Jihlava river from the sewage treatment plant of the veterinaty decontamination institute.

Using the same cotton swabs, samples were taken from the Svratka river near Rajhrad, from the Svratka and Jihlava rivers near the inflow into the Nové Mlýny reservoir, and from the Dyje river after passage through the dike between the middle and lower reservoirs of the Nové Mlýny: waterworks near Dolní Věstonice.

Isolation and identification of salmonellae

Immediately after sampling, the cloacal smears were placed into test tubes with $5 \mathrm{ml}$ of buffered peptone water (BPW), transferred to the laboratory and incubated at $37^{\circ} \mathrm{C}$ for $16-20$ hours. The inoculum from the BPW of a volume of $20 \mu \mathrm{l}$ was transferred to Rappaport's medium (Rappaport et al. 1956) for selective incubation. After 24 and 48 hours of incubation at $37^{\circ} \mathrm{C}$, the samples were inoculated on XLD agar (Imuna, Sarišské Michalany) and incubated here for 24 hours at $37^{\circ} \mathrm{C}$. The suspect colonies of salmonellae were sub-cultivated on Hain's agar (Imuna, Sarišské Michalany) and identified by the biochemical microtests Enterotest I and II (Lachema, Brno). Salmonella antisera (Imuna, Sarišské Michalany) were used for serological identification. Samples of sewage and surface water were elaborated in the same way, the only difference being that the samples were incubated in $225 \mathrm{ml}$ of BPW.

\section{Results}

On 16 May 1991, 79 eggs of black-headed gulls were examined and no salmonellae were found.

Tab. 1 shows the results of examinations of young black-headed gulls performed on 13 June 1991 and 25 June 1991. Among the investigated groups a statistically highly significant difference was found $\left(\mathrm{x}^{2}=73.05, \mathrm{P}<0.001\right)$.

The occurrence of salmonellae in sewage water after discharging into the reservoirs, and in the water of the rivers Jihlava, Svratka and Dyje in June 1991 was as follows:

1) sewage water, Medlov

2) Jihlava river entering the Nové Mlýny waterworks

3) sewage water, Brno-Modřice

4) Svratka river, Rajhrad

5) Svratka river entering the Nové Mlýny waterworks

6) Dyje river, Dolní Věstonice - dike

(sampling 1 June 1991)

(25. June 1991)

(6. June 1991)

(25. June 1991)

(13. June 1991)

(24. June 1991)
S. montevideo

S. typhimurium

S. montevideo

S. montevideo

S. typhimurium

S. typhimurium

\section{Discussion}

The percentage of occurrence of salmonellae in the young black-headed gulls from the nesting colony in the middle reservoir of Nové Mlýny is consi- 
Isolation of salmonellae from young black-headed gulls (Larus ridibundus) from a nesting colony on the Nové Mlýny waterworks (Břeclav district)

\begin{tabular}{|c|c|c|}
\hline Date of examination & 13. 6. 1991 & 25. 6. 1991 \\
\hline Number of birds examined & 96 & 171 \\
\hline Salmonellae not found & 76 & 108 \\
\hline $\begin{array}{l}\text { Salmonella typhimurium } \\
\text { S derby }\end{array}$ & $\begin{array}{l}10 \\
10\end{array}$ & $\begin{array}{r}38 \\
3\end{array}$ \\
\hline S. enteritidis & - & 7 \\
\hline S. agona & - & 5 \\
\hline S. monteviedo & - & 4 \\
\hline S. berta & - & 2 \\
\hline $\begin{array}{l}\text { S. hadar } \\
\text { S. infantis }\end{array}$ & $=$ & $\begin{array}{l}1 \\
1\end{array}$ \\
\hline $\begin{array}{l}\text { S. abony } \\
\text {. }\end{array}$ & - & 1 \\
\hline S. typhimurius and S. enteritidis & - & 1 \\
\hline Proportion of birds with salmonellae & $20.83 \%$ & $36.84 \%$ \\
\hline
\end{tabular}

dered to be very high. The contamination of surface water from the assumed sources, which are probably supplemented by others, less important, down to the large area of Nové Mlýny is extremely important in terms of epidemiology and epizootiology. The water of these relatively shallow reservoirs contains a great amount of organic impurities and in the summer provides an ideal environment for the survival of salmonellae and obviously also for their reproduction.

In previous studies the opinion prevailed that gulls are infected with $\mathrm{s} 1 \mathrm{mo-}$ nellae from various refuse, they become vectors of salmonellae and contribute to their circulation in the environment (Fenlon et al. 1974; Edel et al. 1978; Benton et al. 1983).

If we analyze the obtained facts, we come to the conclusion that it could also be the other way round, i. e. that the salmonellae-contaminated water could be the cause of frequent findings of salmonellae particularly in the young gulls. Nesting gulls fly to feed within a range of $15 \mathrm{~km}$ where waste of animal origin does not occur in larger quantities. During nesting, $85 \%$ of the food of the gulls consist of animal components (fish, worms, insects, mammals) and $11 \%$ of plant components, the remaining part being various mineral and unidentified components (Kondělka 1969). Despite the fact that the volume of the food is relatively large, the daily consumption of food per one bird is $54.78 \mathrm{~g}$ (Stadie 1929), the source of salmonellae in young gulls is probably not the food. Neither does ovarial transfer play a more important role, as the negative results of examinations of eggs from the studied colony showed. It is true that some of the gulls from the colony who are not nesting fly to feed on rubbish tips or larger sewage disposal plants etc., situated farther away, however, their contact with the young gulls is not immediate.

Therefore, the most probable source of infection of the chicks is the polluted water in the colony. In spite of Fenlon (1981) stating that the concentration of salmonellae in waste water is low and cannot allegedly provide the sufficient dose of infection, it is necessary to take into account the well-known fact that the young are much more sensitive to salmonellae infection than the adult birds.

The fact that salmonellae of 7 serotypes were found in 57 out of 377 young black-headed gulls (i. e: $15.1 \%$ ) examined in 1984-1986 in the colony on the pond near Chropyně (Čižek 1990) proves that the high incidence of salmonellae 
in these young gulls is not incidental or rare in the colony of the middle reservoir of the Nové Mlýny waterwork.

On the basis of the present investigations it is not possible to determine what is the relationship between the incidence of salmonellae in gulls and the occurrence of salmonellosis in them, expressed, for instance, in the proportion of losses in the population. Findings of salmonelloses in gulls, however, have been described (Š erý and Strauss 1957; Brand et al. 1988).

The effect of various interactions of pathogens on the incidence of salmonellae and salmonellosis in gulls has not been explained either. Botulism in water birds in the middle reservoir of the Nové Mlýny waterwork has recently been found quite regularly during the summer season. Chytil (1990) described an extensive epizootic there in 1990. In the present study, in samplings from 25 June 1990, we also found a sporadic occurrence of clinical symptoms of botulotoxin poisoning in black-headed gulls.

\section{Acknowledgement}

The authors express their sincere thanks to Mrs. M. Slavíková and Mrs. J. Hofírková.

\section{Využití vyšetř̌ení mládat racka chechtavého(Larus ridibundus) $k$ detekci salmonel v prostredí}

Během června 1991 byly vyšetřeny na přítomnost salmonel kloakální výtěry mládat racka chechtavého (Larus ridibundus) z hnízdní kolonie na prostřední nádrži vodního díla Nové Mlýny (okr. Břeclav). Dne 13. 6. 1991 bylo vyšetřeno 96 mlád’at a salmonely zjištěny u $20(20,83 \%$ ) jedinců (sérotypy Salmonella typhimurium, S. derby); 25. 6. 1991 bylo vyšetřeno 171 mládat a salmonely zjištěny u $63(36,84 \%)$ jedinců ( $S$. typhimurium, $S$. enteritidis, $S$. agona, $S$. montevideo, $S$. derby, $S$. berta, $S$. hadar, $S$. infantis, $S$. abony). Př̀ vyšetření 79 vajec racků chechtavých z 16. 5. 1991 ze stejné kolonie nebyly salmonely zjištěny.

Bylo prokázáno, že voda, která přitékala v červnu 1991 do nádrže řekou Jihlavou i řekou Svratkou byla kontaminována salmonelami ( $S$. typhimurium, $S$. montevideo).

Vyšetření mládat racků chechtavých může být použito $\mathrm{k}$ detekci výskytu salmonel ve vodním prostředí.

\section{Использование исследований птенцов чайки (Larus ridibundus) для определения салмонелп в окружающей среде}

В течение июня 1991 г. проводили исследования клоачных мазков чайки (Larus ridibundus) с целью выявления салмонелл в окружающей среде гнездования гидросооружения Нове-Млины (район Бржецлав). Исследования 96 птенцов проводили 13-го июня 1991 г. и салмонеллы были выявлены у $20(20,83 \%)$ особей (серотипы Salmonella typh murium, S. derby); 25-го июня 1991 г. исследовали 171 птенца и у 63 особей $(36,84 \%)$ установили салмонеллы (S. typh:murium, S. enteritidis, S. agona, S. montevideo, S. derby, S. berta, S. hadar, S. infantis, S. abo- 
ny). В ходе исследования 79 яиц чаек, проводимого 16-го мая 1991 г. на одинаковом гнездовании салмонеллы не были выявлены.

Было установлено, что поступающая в гидросооружения в июне 1991 г. вода рекой Йиглавой и пекой Свраткой была заражена салмонеллами (S. typhimurium, S. montevideo).

Исследования птенцов чаек можно использовать для определения салмонелл в воде.

\section{References}

BENTON, C.-KHAN, F.-MONAGHAN, P.-RICHARDS, V. N.-SHEDDEN, C. B.: The contamination of a major water supply by gulls (Larus spp.). A study of the problem and remedial action taken. Wat. Res., 17, 1983: 789-798.

BRAND, C. J.-WINDINGSTAD, R. M. - SIEGFRIED, L. M. -DUNCAN, R. M. -COOH, R. M.: Avian morbidity and mortality from botulism, aspergillosis, and salmonellosis at Jamaica bay wildlife refuge New York, USA. Colonial Waterbirds, 11, 1988: 284-292.

BUTTERFIELD, J.-COULSON, J. C. - KEARSEY, S. V. - MONAGHAN, P.: The herring gull Larus argentatus as a carrier of Salmonella. J. Hyg. (Camb.). 91, 1983: 429-436.

CHYTIL, J.: Botulismus na jižní Moravě v roce 1988. Ptáci v kulturní krajině, 2. díl, shorník přednášek (Proceedings), II. jihočeská ornitologická konference 25.-26. 2. $1989 \mathrm{v}$ Českých Budějovicích, KSSPOP, 1990: 233-241.

Č́f̌̌EK, A.: Diagnostika, ekologie a možnosti prevence salmonel a patogenních yersinií ve velkochovech zviřat a jejich okolí. Project report, University of Veterinary Science Brno, 1990: $1-98$.

COULSON, J. C.-BUTTERFIELD, J.-THOMES, C.: The herring gull Larus argentatus as a likely transmitting agent of Salmonella montevideo to sheep and cattle. J. Hyg. (Camb.) 91, 1983: $437-443$.

DĚDIČOVÁ, D. - BENEŠ, Č. - ŠRÁMOVÁ, H. - LÁVIČKOVÁ, M.: Surveillance salmonelóz v ČR za rok 1989. In: ZAJÍČEK, D. (red.): Surveillance antropozoonóz Česká republika 1990 ÚVO Pardubice, 1990: 69-111.

EDEL, W.-KAMPELMACHER, E. H.: Salmonella isolation in nine european laboratories using a standardised technique. Bull. Orig. mond. Sante Bull. Wld. Health Org., 41, 1969: $297-306$.

EDEL, W.-SCHOTHORST van, M. - KAMPELMACHER, E. H.: Epidemiological studies on salmonella in a certain area ("Walcheren Project"). I. The presence of salmonella in man, pigs, insects, seagulls and in foods and effluents. Zbl. Bakt. Hyg., Abt. Orig., A 325, 1976: $476-4.84$.

EDEL, W.-SCHOTHORST van, M.-LEUSDEN van, F. M. - KAMPELMACHER, E. H.: Epidemiological studies on salmonella in a certain area ("Walcheren Project"). III. The presence of salmonella in man, insects, seagulls and in foods, chopping-block scraping from butcher's schops. Zbl. Bact. Hyg., I. Abt. Orig., A 242, 1978: 468 - 480.

FENLON, D. R.: Seagulls (Larus spp.) as vector of salmonella in gull faeces. J. Hyg. (Camb.), 86, 1981: 195-202.

FENNEL, H.-JONES, P. B. - MORRIS, J.: Pollution of a water storage reservoir by roosting gulls. Water Treatment and Examination. 23, 1974: 5-20.

FRICKER, C. R.: A note on salmonella excretion in the black headed gull (Larus ridibundus) feeding at sewage treatment works. J. appl. Bacter., 56, 1984: 499-502.

GLUNDER, von G. - NEUMANN, U.-BRAUNE, S. - PRÜTER, J.-PETERSEN, S.VAUK, G.: Zum Vorkommen von Campylobacter spp. und Salmonella spp. bei Möwen in Norddeutschland. Dtsch. tierärztl. Wschr. 98, 1991: 152-155.

JOHNSTON, V. S. - HOPKINS, G. F. - MacLACHLAN, G. K. - SHARP, J. C. M.: Salmonella in sewage effluent and the relationship to animal and human disease in north of Scotland. Vet. Rec., 119, 1986: 201-203.

KOMÎNKOVÁ, B.-BLATNÝ, J.: Salmonely $\mathrm{v}$ povrchových a odpadních vodách vybraných lokalit okr. Ždár nad Sázavou. Čs. Hyg., 32, 1987, 3: 146-155.

KONDĚLKA, D.: Potrava racka chechtavého (Larus ridibundus). Ph. D. Thesis, Pedagogical Faculty, Ostrava, 1969.

MONAGHAN, P.-SHEDDEN, C. B.-ENSOR, K.-FRICKER, C. R.-GIRDWOOD R. W. A.: Salmonella carriage by herring gulls in the clyde area of Scotland in relation to their feeding ecology. J. appl. Ecology, 22, 1985: 669-680. 
LITERÁK, I. - KRAML, F.: Výskyt salmonel u volně žijících ptáků (Passeriformes, Lariformes). Vet. Med. (Praha), 30, 1985, 6: 353-358.

RAPPAPORT, F.-KONFOTI, N.-NAVON, B.: A new enrichment medium for certain salmonellae. J. clin. Pathol., 9, 19656: 261-266.

REILLY, W. J.-FORBES, G. I.-PATERSON, G. M.-SHARP, J. C. M.: Human and animal salmonellosis in Scotland associated with environmental contamination, 1973-79. Vet. Rec., 108, 1981: 553-555.

STADIE, R.: Beiträge zur Biologie der schlesischen Lachmövenkolonien. Berichte d. Ver. Schlesischer Ornith., 1929, 2: 23-89.

SERÝ, V.-STRAUSS, J.: Výskyt ornitózy a salmonelózy u racka chechtavého (Larus ridibundus). Čs. epidem., mikrobiol., imunol., 6, 1957, 3: 231-240.

ŠRÁMOVÁ, H. - DĚDIČOVÁ, D.-PETRĂS̆, P. - BENEŠ, Č.: Epidemiologický výskyt alimentárních nákaz bakteriálního původu v České republice v letech 1979-1989. Čs. epidem., mikrobiol., imunol., 40, 1991, 2: 74-83.

WILLIAMS, B. M.-RICHARDS, D. W.-LEWIS, J. Salmonella infection in the herring gull (Larus argentatus). Vet. Rec., 98, 1976: 51. 